\title{
Effect of Densities of Planting on Yield and Essential Oil Components of Fennel (Foeniculum vulgare Mill Var. Soroksary)
}

\author{
Jalal Khorshidi (Corresponding author) \\ Department of Horticulture Science, University of Tehran \\ Karaj, Iran \\ Tel: 98-914-816-5105_E-mail: jalal_khorshidi2006@yahoo.com \\ Mohammad Fakhr Tabatabaei \\ Department of Horticulture Science, University of Tehran \\ Karaj, Iran \\ Reza Omidbaigi \\ Department of Horticulture Science, University of Tarbiat Modarres \\ Tehran, Iran
}

Fatemeh Sefidkon

Research Institute of Forests and Rangelands

Tehran, Iran

\begin{abstract}
In order to study the effect of different densities of planting on yield and essential oil components of Fennel (Foeniculum vulgare Mill Var. Soroksary), an experiment was carried out in college of agriculture Karaj at 2008. Experiment was conducted based on completely randomized block design with three replication and five plant densities. Five plants spaces were 10, 15, 20, 25 and $30 \mathrm{~cm}$ on the row. The distance between rows in all treatments was $40 \mathrm{~cm}$. The essential oil extracted by water distilled method from seeds and essential oil was analyzed by gas chromatography (GC). The higher essential oil percentage (\% 3.53) was obtained with the lowest densities of planting. The higher percentage of anethole (\%83.07), estragol (\%3.47), fenchone (\%8.04), p-cymene (\%4.45), $\alpha$-terpinene $(\% 0.54)$, sabinene $(\% 0.51)$, and $\alpha$-Pinene $(\% 0.48)$ were obtained with space between plants $25,10,20,20,15,20$, and $25 \mathrm{~cm}$, respectively.
\end{abstract}

Keywords: Fennel, Density, Essential oil, Anethole

\section{Introduction}

In the world today, the traditional food, forage and fiber crops are not the only plants of key agricultural and trade significance, but they also include plants whose secondary metabolites are valued for their characteristic aromatic or therapeutic attributes, or as main natural inputs to the proliferating perfumery and chemical industries. Bitter fennel (Foeniculum vulgare Mill. Var. soroksary) is a perennial hemicryptophyte, common in the Mediterranean basin and known since antiquity as a medicinal and aromatic herb. The fruit of bitter fennel is commonly used us a natural remedy against digestive disorder. Bitter fennel is also used to flavor foods, liqueurs and in the perfumery industry (Lucinewton et al., 2005). Present world market is around US\$ 80 million. Iran exports these produce worth US\$ 10 million (Masood et al., 2004). The production of essential oils not only depends upon the metabolic state and present developmental differentiation program of the synthesizing tissue, but also is highly integrated with the physiology of the whole plant. Besides, the oil productivity is friendly to ecophysiological, environmental and other factors (Voirin et al, 1990). Plant spacing is an important factor in determining the microenvironment in the fennel field. The optimization of this factor 
can lead to a higher yield in the crop by favorably affecting the absorption of nutrients and exposure of the plant to the light. According to results of Verzalova et al (1988) row spacing did not effect on the plant height but number of umbel and seed yield per plant was increased at the wider spacing. Masood et al (2004) investigated the effect of row spacing $(40,50,60$, and $70 \mathrm{~cm})$ on morphological characters and seed yield of fennel and reported that the greatest plant height, seed yield per umbel, and seed yield per hectare were obtained with the lowest row spacing but the lowest plant height, seed yield per umbel, and seed yield per hectare were obtained with the greatest row spacing.

Bianco and Damato (1994) reported that plant density not affected on plant height at flowering of primary umbel, number of stem and umbel per plant, yield per plant and per hectare. Akbariani et al (2006) studied the effect of plant density on seed yield of Coriander (Coriandrum sativum) and showed with increasing of plant density seed yield decreased significantly. Hasanali et al (2002) with study the effect of different plant densities on yield dry material of Thyme (Thymus vulgaris) showed that the higher yield of dry material was obtained with $15 \mathrm{~cm}$ densities of planting.

Arabasi and Bayran (2004) with planting sweet basil in three plant density (20, 40 and 60 plants m-2) reported that the highest amount of dry matter, percentage and the yield of effective substances produced in 20 plant $\mathrm{m}^{-2}$. Aflatuni (2005) mentioned that planting pattern had no significant effect on essential oil amount and composition of mint. In this study was considered the effect of different densities of planting on yield and essential oil components of Fennel.

\section{Materials and methods}

This experiment was carried out in the Tehran university, college of agriculture of Karaj in 2008 (Table1). Field was plowed during the fall season and was disked before sowing time to provide a proper seedbed. Experiment was conducted based on completely randomized block design with three replications and five plant densities. The experiment includes 3 blocks and each block is contained 5 plots. Each plot size was $2.5 \times 1.5 \mathrm{~m}$. Distance between blocks and plots were $1 \mathrm{~m}$. Five plant spaces were $10,15,20,25$, and $30 \mathrm{~cm}$. The distance among rows in all treatments was $40 \mathrm{~cm}$. Each plot was consisted of five rows. The bitter fennel seeds were sown at the 7th March 2008. Irrigation were done as: 1. 2-3 days interval irrigation until germination stage, 2. 4-5 days interval irrigation from germination to appearance first flowers stage, and 3. 7 days interval irrigation from appearance first flowers to harvest stage. Thinning was done when plants had 4-5 leaves. In order to better growing of plants, crust breaking operation were done at three stages (18th April, 4th May, and 19th May).Ten plants were selected at random from each plot for recording individual plant observation. All agronomic practices were keeping normal and uniform for all the treatments. Then seeds harvested after ripening at two stages (20th August and 30th August) and dried in shade for 72 hour. In order to extraction of essential oil, $15 \mathrm{gr}$ of seeds powdered and then essential oil isolated by water distillation for $4 \mathrm{~h}$ and with three replications. The essential oils were separated from the aqueous layer, dried over anhydrous sodium sulfate and calculated average of essential oil yield for three replications and finally were stored in the refrigerator until analysis time. In order to identify the essential oil components, gas chromatography was carried out using a GC Thermo-UFM with Ph-5 column (10m, 0.1 mm ID, $0.4 \mathrm{FT})$. Owen temperature was performed as follow: $60^{\circ} \mathrm{C}$ to $285^{\circ} \mathrm{C}$ at $80^{\circ} \mathrm{C} / \mathrm{min}$; injector temperature $280^{\circ} \mathrm{C}$; detector temperature, $280^{\circ} \mathrm{C}$; carrier gas, $\mathrm{He}(0.5 \mathrm{ml} / \mathrm{min})$ with chrome-card software and area normalization method. In order to identify the essential oil components, relative retention time of components was compared together.

\section{Results and discussion}

Results indicated that essential oil percentage was affected significantly by different densities of planting, as the maximum essential oil percentage (\%3.53) was obtained with the minimum plant density (space between plants on the $30 \mathrm{~cm}$ row) and the minimum essential oil percentage (\%3.1) was obtained with the maximum plant density (space between plants on the $10 \mathrm{~cm}$ row)(see Table2). The higher percentage of anethole (\%83.07), estragol (\%3.47), fenchone (\%8.04), p-cymene (\%4.45), $\alpha$-terpinene ( $\% 0.54)$, sabinene ( $\% 0.51)$, and $\alpha$-pinene $(\% 0.48)$ were obtained with space between plants on the $25,10,20,20,15,20$, and $25 \mathrm{~cm}$ row, respectively. While the minimum percentage of anethole (\%81.98), estragol (\%3.39), fenchone (\%6.97), p-cymene (\%3.74), $\alpha$-terpinene (\%0.45), sabinene (\%0.39), and $\alpha$-pinene $(\% 0.32)$ were obtained with space between plants on the $20,15,25,10,25,10$, and $10 \mathrm{~cm}$ row, respectively (see Table3, and Fig 1 to 7). In general, with decreasing of space between plants on the row essential oil percentage was increased. Ahmad and Haque (1986) with study the effect of different plant densities on yield essential oil and oil of Nigella (Nigella sativa) showed that the higher yield of essential oil and oil were obtained with the lowest of plant density. Shalaby and Razin (1994) with study on the Thyme (Thymus vulgaris) reported that the maximum yield of dry matter and essential oil were obtained with the lowest of plant density. El-Gandi et al (2001) suggested that the highest of essential oil percentage per plant in Sweet basil (Ocimum basilicum L.) was obtained with the lowest of plant density but total yield of essential oil was increased with the increasing of plant density. Najafi and Moghadam (2002) reported that with increasing the plant density, seed and biological yield were increased. Wajid et al (2004) showed that plant population had significant effect on yield component. For production of essential oil, multiple factors are effective including: plant ontogeny, site of oil production, photosynthesis, photoperiodic modulation, light quality, seasonal and climatic variations, nutritional relationships, plant growth regulators, plant density, moisture, salinity, temperature. In 
general, each factor that is influenced on the photosynthesis can be affected on the production of essential oil. Plant density by affecting the absorption of nutrients and exposure of the plant to the light can be affected on the photosynthesis and production of essential oil.

\section{Conclusion}

Fennel plant is one of the most interesting research plants. It is between medicinal and aromatic plant. Plant density is an important factor in determining of fennel yield. Results of this study showed that influence of different densities of planting on yield essential oil were significant at the 0.05 probability levels. But different densities of planting have different effect on the essential oil component.

\section{Acknowledgement}

The authors are grateful to University of Tehran, Mr Kaveh Mollazade, Rahmat Mohammadi, and Khaled Ahmad Aali for their valuable assistance and technical support.

\section{References}

Aflatuni, A. (2005). The yield and essential oil content of mint (Mentha sp.). Academic dissertation to be presented with the assent of the faculty of science. University of Aula. pp, 1-50.

Ahmed, N.U., \& Haque, K.R. (1986). Effect of row spacing and time of sowing on the yield of black Nigella (Nigella sativa L.) in Bangladesh. Journal of Agricultural scinience, 1, 21-24.

Akbariania, A., Daneshian, J., \& Mohammadbiegi, F. (2006). Effect of nitrogen fertilizer and plant density on seed yield, essential oil and oil content of Coriandrum sativum L. Revive researches of medicinal and aromatic plant of Iran, 22(4), 410-419.

Arabasi, O., \& Bayram, E. (2004). The effect of nitrogen fertilization and different plant densities on some agronomic and technologic characteristic of basil (Ocimum basilicum L.). Journal of Agronomy, 3(4), 255-262.

Damato, G., Bianco, V., \& Laterza, M. (1994). First results of plant density and nitrogen rate on yield and quality of Florence fennel seeds. ISHS Acta Horticulture, 362.

El-Gendy, SA., Hosni, AM., Ahmed, SS., Omer, EA., \& Reham, MS.(2001). Variation in herbage yield and oil composition of Sweet basil (Ocimum basilicum L.). Journal of Agricultural scinience, 9, 915- 933.

Lucinewton, S., Raul, N., Carvalho, J., Mirian, B., Lin, C., \& Angela, A. (2005). Supercritical fluid extraction from fennel (Foeniculum vulgare) global yield, composition and kinetic data. Journal of Supercritical Fluid, 35, 212-219.

Masood, A., Syed Asgha, H., Mohammad, Z., \& Abdur, R. (2004). Effect of different sowing season and row spacing on seed production of fennel (Foeniculum vulgare). Journal of Biological Science, 7(7), 1144-1147.

Naghdibadi, H., Yazdani, D., Nazari, F., \& Mohammadali, S. (2002). Effect of different densities of planting on essential oil component of Thymus vulgaris. Revive researches of medicinal and aromatic plant of Iran, 1, 51-57.

Najafi, F., \& Moghadam, P.R. (2002). Effect of irrigatiom regimes and plant density on yield and agronomic characteristics of blond psyllium (plantago ovata). Journal of Agricultural scinience Technology, 16, 59-65.

Shalaby, AS., \& Razin, AM. (1994). Dense cultivation and fertilization for higher yield of thyme (Thymus vulgaris). Horticulture Abstrac,. 64, abts. 1375.

Verzalova, I., Kocurkova, B., \& Stavkova, I. (1988). The response of two cultivars of fennel (Foeniculum vulgare var. vulgare Mill) to row spacing. Acta Horticulture, 15(2), 101-106.

Voirin, B., Brun, N., \& Bayat, C. (1990). Effects of day length on the monoterpene composition of leaves of Mentha piperata. Phytochemistry, 29, 749-755.

Wajid, A., Hussian, A., Ahmad, A., Goheer, A.R., Ibrahim, M., \& Mussaddique, M. (2004). Effect of sowing date and plant population on biomass, grain yield and yield component of wheat. Journal of Agricultural Biology, 6, 1003-5.

Table 1. Geographical coordinates, average annual rainfall and mean annual temperature of Karaj

\begin{tabular}{lllll}
\hline longitude & latitude & height of sea level $(\mathrm{m})$ & $\begin{array}{c}\text { average annual } \\
\text { rainfall }(\mathrm{mm})\end{array}$ & mean annual temperature $\left({ }^{\circ} \mathrm{c}\right)$ \\
\hline $50^{\circ} 59^{\prime} \mathrm{E}$ & $35^{\circ} 47^{\prime} \mathrm{N}$ & $1312 / 5$ & 230 & $14 / 3$ \\
\hline
\end{tabular}


Table 2. Relationship between space between plants and percentage of essential oil

\begin{tabular}{lccccc}
\hline Space between plants $(\mathrm{cm})$ & 10 & 15 & 20 & 25 & 30 \\
\hline Essential oil (\%) & 3.1 & 3.22 & 3.33 & 3.33 & 3.53 \\
\hline
\end{tabular}

Table 3. Relationship between plant density and percentage of essential oil component

\begin{tabular}{llllllll}
\hline RT & RI & compound & $10 \mathrm{~cm}$ & $15 \mathrm{~cm}$ & $20 \mathrm{~cm}$ & $25 \mathrm{~cm}$ & $30 \mathrm{~cm}$ \\
\hline 1.42 & 954.03 & $\alpha$-Pinene & 0.32 & 0.38 & 0.41 & 0.48 & 0.45 \\
1.5 & 984.88 & Sabinene & 0.39 & 0.44 & 0.51 & 0.42 & 0.47 \\
1.59 & 1039.64 & $\alpha$-Terpinene & 0.51 & 0.54 & 0.5 & 0.45 & 0.51 \\
1.62 & 1054 & P-Cymene & 3.74 & 3.95 & 4.45 & 4.06 & 3.8 \\
1.76 & 1117.65 & Fenchone & 7.74 & 7.63 & 8.04 & 6.97 & 7.94 \\
1.96 & 1223 & Estragol & 3.47 & 3.39 & 3.43 & 3.44 & 3.41 \\
2.14 & 1321.05 & E-Anethol & 82.52 & 82.51 & 81.98 & 83.07 & 82.68 \\
\hline
\end{tabular}

RT: Retention time

RI: Retention index

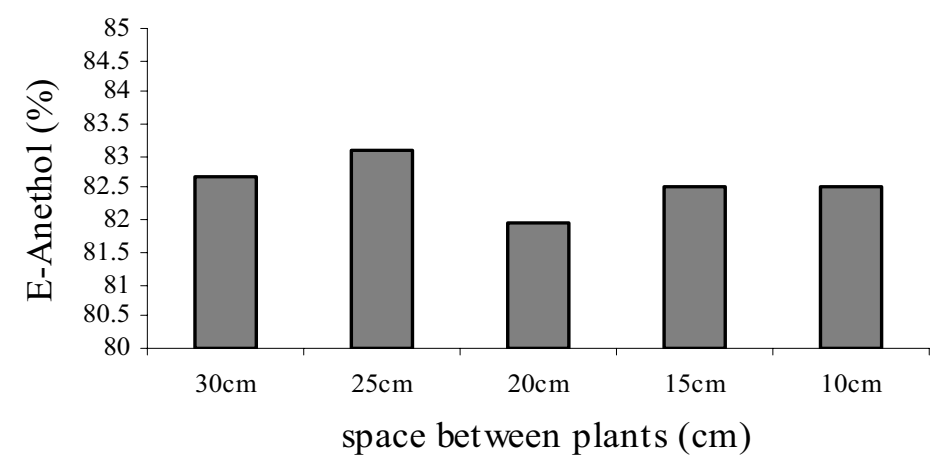

Figure 1. Relationship between percentage of E-Anethol and space between plants

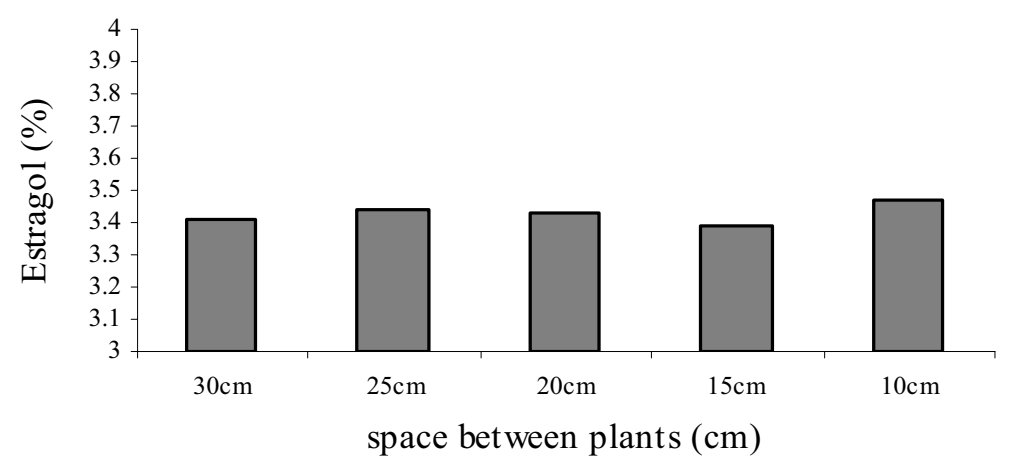

Figure 2. Relationship between percentage of Estragol and space between plants 


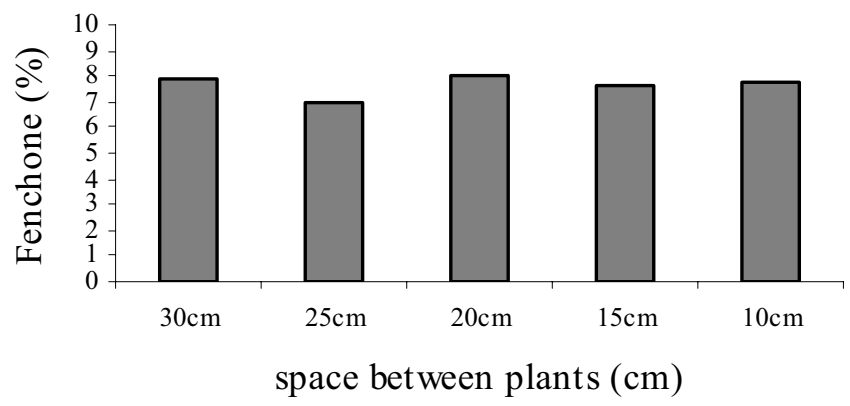

Figure 3. Relationship between percentage of Fenchone and space between plants

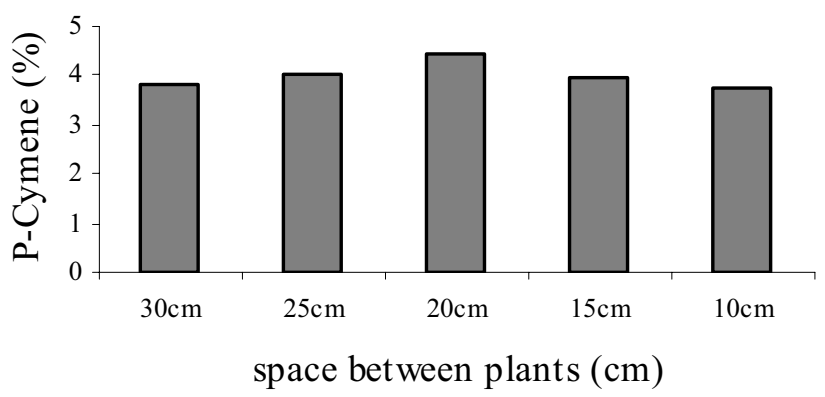

Figure 4. Relationship between percentage of P-Cymene and space between plants

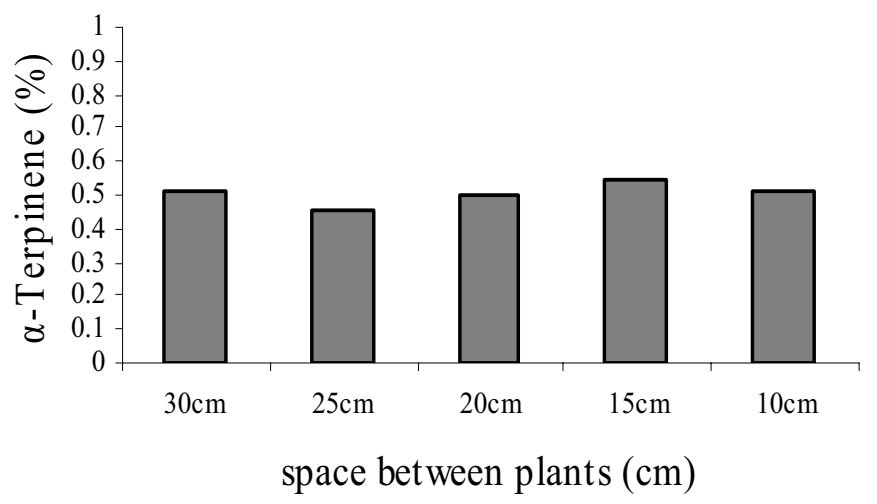

Figure 5. Relationship between percentage of $\alpha$-Terpinene and space between plants 


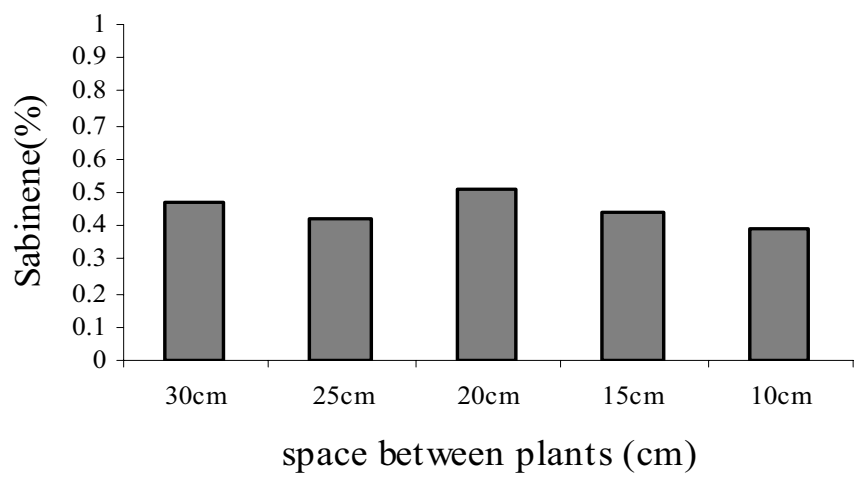

Figure 6. Relationship between percentage of Sabinene and space between plants

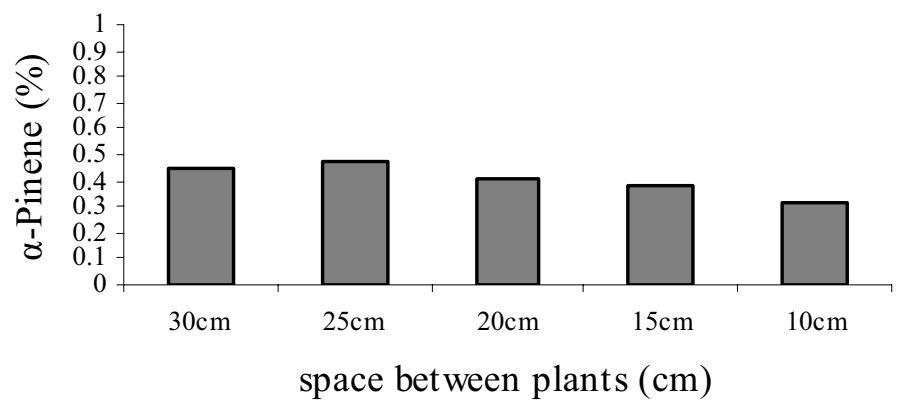

Figure 7. Relationship between percentage of $\alpha$-Pinene and space between plants 